\title{
ЕКСПЕРИМЕНТАЛЬНО-ГЕНЕТИЧНИЙ МЕТОД ЯК ЕФЕКТИВНИЙ ЗАСІБ ДОСЛІДЖЕННЯ ПРОБЛЕМИ ПСИХОКОРЕКЦІЇ ПІДЛІтКОВОї АДИкЦІї
}

\begin{abstract}
Стаття присвячена розкриттю сутності експерментально-генетичного методу та його імплементації в дослідження проблеми психокорекиії підліткової адикиії. Автор розкриває історичний шлях становлення цьвого методу та наводить приклади застосування у праиях вітчизняних науковців. Стверджує, щз змістовною основою технологї методу є принцип єдності експериментального та генетичного напрямків розвитку, які забезпечують перебіг дослідження у максимально природних умовах перебування людини, а також можливість створення відповідного простору реалізаџї̈ нею безлічі варіантів моделювання особистісного розвитку та існування.
\end{abstract}

Ключові слова: експериментально-генетичний метод, адикиї̈, підлітки, психокорекція.

Постановка проблеми. Науковці упродовж тривалого часу на теоретичному та емпіричному рівнях осмислювали різноманітні феномени психіки через призму культурноісторичної теорії та створили визначну методологічну процедуру для вивчення розвитку психіки - експериментально-генетичний метод. Впроваджений Л. Виготським у психологічну науку він набув окремого вагомого статусу. Цей концептуальний феномен, в основу якого покладено базові принципи розвитку психіки, проходить через основні праці О. Леонтьєва, П. Гальперіна, О. Запорожця, Д. Ельконіна, В. Давидова, С. Максименка і сягає сьогодення через науковий доробок Є. Бугрименка, Я. Гошовського, Ж. Вірної, 3. Карпенко, 3. Ковальчук, Т. Комар, В. Мєдвєдєва, Т. Щербан та ін.

В усіх працях спільною основною думкою є твердження, що специфічні форми психіки не дані людині від народження, а лише задані як суспільні зразки, тому психічний розвиток здійснюється у вигляді засвоєння цих зразків, зокрема й у процесі цілеспрямованого навчання та виховання. Варто зазначити, що експериментально-генетичний метод у працях Я. Гошовського, В. Давидова, Л. Зазуліна, З. Ковальчук, Н. Кучеренко, С. Максименка використовується як одна 3 найважливіших емпірико-дослідних ланок розвивального навчання $[4 ; 5 ; 6 ; 7 ; 9 ; 10]$.

Змістовні та методичні аспекти проблеми адиктивної поведінки підлітків у значній частині наукової літератури уже досліджені. Проте все ще недостатньою є кількість наукових робіт, які б розкривали повною мірою проблему корекції адиктивної поведінки підлітків шляхом впровадження експериментально-генетичного методу.

Метою статті $\epsilon$ розкриття сутності експериментально-генетичного методу як ефективного засобу дослідження проблеми психокорекції підліткової адикції.

Виклад основних результатів дослідження. Одне з основних завдань генетичної психології як напрямку, який зараз перебуває в процесі становлення та заслуговує на визнання - це зрозуміти цілісну особистість в ії саморозвитку. Вивчення особистості та усіх iii структурних складових потребує впровадження адекватного об'єкта відповідного методу дослідження. Генетично-психологічний погляд на особистість пов'язаний із розумінням ії як унікальної цілісності, що постійно саморозвивається, саморегулюється і є носієм довічного вселюдського духу [8, с. 8].

С. Максименко стверджує, що експериментально-генетичний метод закріплює систему в розвитку, яка теж вимагає відповідної системи предметно-перетворювальних активностей, у процесі виконання яких в особистості формується цілий ряд психологічних новоутворень. Усе це відбувається завдяки різноманітним способам формування вищих психічних функцій, яким сприяє експериментально-генетичний метод.

Водночас саме перетворення поєднує генетичний та структурно-функціональний моменти об'єктивної реальності й задає тим самим подібні структури самому психічному, які здебільшого реалізуються як способи аналізу. Завдяки механізмам інтеріоризації, 
способи перетворення виступають психологічними механізмами предметної діяльності суб'єкта [9, т. 1, с. 69].

Отже, закономірності психічного розвитку можна інтерпретувати через психічні процеси, які регулюють діяльність та поведінку особистості. Ці закономірності детерміновані даним процесом формування, що відбувається завдяки експериментальногенетичному рівню.

Впровадження експериментально-генетичного методу є частиною соціального у формуванні психіки особистості, яка, таким чином, може розумітися як історичний продукт. Отже, завдяки цьому вчений С. Максименко схильний до визначення експериментально-генетичного методу через призму історичного підходу та характеризувати його як історико-генетичний.

Цей метод не можна ототожнювати з будь-якими іншими уже відомими методами, зокрема, спостереженням, анкетуванням, бесідою і т. ін. Це особливий підхід щодо дослідження психічного і водночас як методологічний принцип та спосіб вивчення психології особистості в цілому. Тобто, цей метод може взяти на озброєння будь-яку методику з переліку традиційних, до прикладу, експеримент чи спостереження.

Вивчати цілісну особистість в іiі саморозвитку та єдності біосоціальної детермінованості є завданням та загальною метою генетико-моделюючого методу. Саме тому загальні принципи організації методу неодмінно відтворюють філософію буття об'єкта вивчення. Таким чином, змістовною основою технології методу є принцип єдності експериментального та генетичного напрямків розвитку, які забезпечують перебіг дослідження у максимально природних умовах перебування людини, а також можливість створення відповідного простору реалізації нею безлічі варіантів моделювання особистісного розвитку та існування.

Твердження щодо соціально детермінованої свідомості людини, положення про

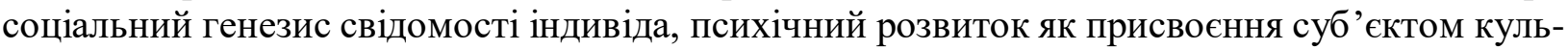
турних набутків суспільства $є$ діалектичною канвою експериментально-генетичного методу [4].

Експериментально-генетичний метод, як вважає С. Максименко, не використовувався і не може використовуватися для дослідження особистості як такої, однак ті реальні емпіричні результати, отримані при вибірковому його застосуванні, узагальнення, здійснені у межах теорії розвивального навчання, дозволяють розглядати його як концептуальне підгрунтя створення методу вивчення особистості. Завдяки цьому досліджено механізми виникнення і розвитку окремих вищих психічних функцій: суб'єкт, застосовуючи / створюючи спеціальні засоби, привласнює загальнолюдські здібності, що існують в соціальному оточенні як опредметнені прояви інших суб'єктів, і перетворює їх у власні здібності як вищі психічні функції [9].

Хоч і цей метод спрямований на те, щоб визначати, як працює така унікальна система, як особистість, яка саморозвивається та створює власну цілісність, проте, на думку вченого, експериментально-генетичний метод може трактуватися і як “типовий”. Варто зазначити, що сама цілісність більшою мірою залишається поза увагою, а дослідникові необхідно іï добудовувати через призму власних роздумів та міркувань, опираючись на конкретні та часткові результати. Через відмінності об'єктів вивчення 3 реальними експериментальною метою власне і виникає неоднозначна логічна обумовленість розвою й технології, які визначаються для використання експериментально-генетичного та генетикомоделюючого методів.

Використання методу в дослідженнях дозволяє глибоко і цілісно розкрити походження певного психічного процесу. Змістово-функціональна сутність експериментальногенетичного методу полягає в тому, що він дає можливість досліджувану вибірку провести на дітях, котрі позбавлені реакції на відповідний психічний процес, а потім, виходячи із заданої гіпотези, у лабораторних умовах сформувати цей процес. Тобто за допомогою методу здійснюється моделювання процесу, який має місце в житті, і постає сприятлива 
нагода розібратися в тому, що ж приховується за переходами від одного рівня розвитку до іншого, оскільки є можливість цей перехід експериментально вибудувати.

Експериментально-генетичне дослідження передбачає виокремлення змістовної одиниці аналізу в просторі наукової дисципліни як феномена, що є результатом опредметнення вищих психічних функцій великої кількості людей в історичному масштабі. Потім відбувається своєрідне “переведення" отриманого матеріалу у форму навчального предмета і привласнення його як навчального завдання, тобто засобу вирішення конкретної навчальної проблеми. Результатом такого процесу є виникнення нової психічної структури вищого рівня складності - одиниці свідомості, якого завдяки подвійному опосередкуванню визначаються подальші процеси “вростання" індивіда в культуру, опосередковуючи їх зсередини [8].

Експериментально-генетичному методу притаманна та перевага, про яку веде мову С. Максименко, стверджуючи, що головна вимога до методів наукового дослідження в психології - давати ймовірне знання, досягати об'єктивності відтворення психічних феноменів оптимальним шляхом відповідно до закону оптимальності “...3 метою гармонізувати психіку, дії, діяльність і творчість - з мінімальним докладанням енергії, часу і праці" [8, с. 37].

У наукових працях П. Гальперіна експериментально-генетичний метод реалізується як можливість планомірного поетапного формування розумових дій i понять. Його теоретичне осмислення й емпіричне використання дозволили отримати низку грунтовних науково підтверджених фактів, що стосуються мисленнєвого розвитку особистості дитини, та водночас на рівні тривалого й розгалуженого психолого-педагогічного експерименту підтвердити гіпотезу Л. Виготського про системний характер і смислову будову свідомості людини [2].

Широкі можливості для вирішення проблеми підліткової адикції пропонує якраз експериментально-генетичний метод дослідження як один із найперспективніших методів розвивальної психології. Сутнісні основи його викладено у працях Є. Бугрименка, Ж. Вірної, Я. Гошовського, Н. Калини, 3. Карпенко, 3. Ковальчук, О. Мусіяки, Т. Щербан. Головні конструкти цього методу в найрізноманітніших модифікаціях активно застосовуються у психологічній практиці в різнотипних освітніх інституціях усіма прихильниками генетичної психології.

Психологічний зміст експериментально-генетичного методу базується на таких основних концептуальних положеннях. Як зазначає С. Максименко, логіка цього методу передбачає активне моделювання та відтворення у спеціальних умовах закономірностей виникнення й становлення в онтогенезі психологічних функцій. Модель, створена цим ученим, відповідає внутрішній структурі самого психічного процесу. Отже, цей процес спочатку відтворюється у вигляді моделі певної діяльності, а потім здійснюється спеціальним способом організації активності суб’єкта. Навчальне завдання в експериментально-генетичному дослідженні $\epsilon$ засобом породження та розвитку психічних процесів [8].

Експериментально-генетичний метод, розроблений С. Максименком, заснований на таких принципах:

1) аналізу за одиницями (вичленування вихідного суперечного відношення, що породжує клас явищ як ціле); головне завдання - виділити цілісні риси і моменти кожного психологічного явища, які зберігають сутність цілого;

2) історизму (єдність генетичної та експериментальної лінії в дослідженні); завдання дослідника полягає у генетичному вивченні структурних компонентів психічного процесу, який розгортається у часі; охопити у дослідженні процес розвитку як психічного явища в усіх його фазах та змінах - від моменту виникнення до загибелі, що означає розкриття його природи і пізнання його сутності;

3) системності (цілісний розгляд психічних утворень); система уявлень, що розвивається, потребує відповідних предметно-перетворювальних дій, виконання яких 
формує психологічні новоутворення в суб'єкта; тож принцип системності постає єднальною ланкою між абстрактним та конкретним, пов'язуючи знання, що розвивається, з предметно-перетворювальною діяльністю, яка породжує ці знання;

4) проектування та моделювання (активного моделювання, відтворення психіки в особливих умовах); таким чином в теорії експериментально-генетичного методу розкривається якісна відмінність від інших психологічних методів, імплементується створення моделей, що є прототипами реально існуючих психічних процесів [6].

На наш погляд, сутність дефініції цього методу має досить чіткі обриси і позиції, так у термінологічному вимірі С. Максименка змістово-семантична i структурно-функціональна сутність експериментально-генетичного методу включає: теорію, на основі якої його створено; проектування (моделювання); перетворювальний (формувальний) експеримент; діагностику (фіксацію) проміжних та кінцевих станів людини; оцінку психологічних новоутворень особистості тощо. Експериментально-генетичний метод допомагає систематизувати різнопланові знання щодо дослідження певного психічного процесу, дослідити його внутрішню структуру шляхом виокремлення базових компонентів, які обумовлюють змістове наповнення аналізованого психічного феномена, а також дає можливість простежити його розвивальний потенціал.

Логіка експериментального дослідження предмета генетичної психології передбачає не лише констатацію упродовж спостереження чи формувального експерименту певних емпіричних форм прояву психіки особистості, а й активне їхнє відтворення і моделювання в особливих умовах. Учений С. Максименко цілком обгрунтовано переконує, що таке моделювання призводить до розкриття сутнісних параметрів певних психологічних явищ, функцій і здібностей, зокрема дозволяє з'ясувати онтогенез їхнього виникнення i становлення [8; 9].

У ракурсі нашого дослідження “особливими умовами” можна вважати корекцію підліткової адикції, зокрема психокорекційний вплив на підлітка-адикта, через спілкування між суб'єктами спільної корекційної діяльності, кожен з яких має свої унікальні особистісні параметри, долає різномодальні за походженням і проявом варіанти нужди та прагне почути і бути почутим, а загалом хоче бути самодостатнім та самореалізованим індивідом. Актуальність проблеми ефективної психокорекційної роботи зумовлюється насамперед пошуком нових психологічних закономірностей корекції в нових умовах, адже психолог для підлітка $є$ джерелом корисної інформації, зразком, прикладом, який впродовж своєї діяльності демонструє моделі поведінки, базовані на оптимальних нормах та цінностях суспільства, і таким чином тією чи іншою мірою впливає на розвиток особистості підлітка. На цю обставину як важливий чинник вказують учені, котрі вивчають особливості застосування експериментально-генетичного методу, у психокорекційній роботі в тому числі $[1 ; 2 ; 3 ; 4 ; 5 ; 9 ; 10]$.

Експериментально-генетичний метод у контексті культурно-історичного підходу до онтогенезу особистості тлумачиться як такий, що відбувається за посередництвом соціально заданих зразків нормативної поведінки. Обгрунтування емпіричних засад наших досліджень щодо вивчення психокорекційної роботи з підлітками-адикатами, яка перебуває у площині активної детермінуючої дії особистісних чинників взаємодіючих сторін, якраз спиралося на базові постулати експериментально-генетичного методу.

Згідно з функціональною семантикою цього методу доцільність конкретного методичного прийому визначається тим, наскільки він відповідає поставленій двоєдиній меті та сприяє реалізації виокремленої системи дій. Використання певних прийомів у процесі психологічного спілкування має зумовлюватися поставленою розвивальною метою та необхідністю створення моделі, котра була б адекватною родовій діяльності. Експериментально-генетичний метод передбачає конструювання змісту психокорекційного матеріалу та його реалізацію упродовж відповідної психологічної роботи з підлітком 3 метою виявлення специфіки діяльності, що повинна забезпечувати цілеспрямоване 
формування певного психічного процесу та виокремлювала конкретні способи дій, які сприяють розвитку.

Аналізований метод інкультурується в реальні психодіагностичні практики багатьох учених. Так, вивчаючи феноменологію біографічного дослідження особистості як складової експериментально-генетичного підходу до іiі розвитку, Р. Семенова-Пономарьова віднаходить багато опосередкованих типологічних збігів у парадигмі “онтопсихологія (Б. Ананьєв) - генетична психологія (С. Максименко)". На думку ученої, біографічний метод застосовується як засіб вивчення індивідуальності конкретних людей в їхньому розвитку, а це відповідає загальній генетичній і психодіагностичній спрямованості комплексних емпіричних досліджень особистості [5 с. 67].

Оскільки біографічна психодіагностика активно доповнює лабораторно-експериментальну й грунтується на реконструкції цілісного індивідуального способу життя, на виявленні стійких засобів взаємодії людини з обставинами макро- і мікросередовища, на 3'ясуванні комплексу життєвих показників особистісних властивостей, то іiі критерії повинні використовуватись як валідні й достовірні показники онто- й соціогенезу. Отож у контексті науково-психологічного емпіризму стверджується, що “біографічний метод безперечно належить до генетичних" [8, с. 264].

Активне методологічне й методичне запровадження експериментально-генетичного методу в реальний навчальний процес, зокрема в шкільний курс фізики, дозволило О. Савицькій досягнути помітних успіхів у розвитку інтелектуальної рефлексії школярів, а також доказати на цьому прикладі плідний і розвивальний характер цього методу. Дотримуючись ідеї побудови навчального матеріалу за принципом сходження від абстрактного до конкретного, використовуючи розроблені В. Давидовим, С. Максименком, В. Рєпкіним та іншими представниками школи розвивального навчання принципи створення програм, авторка розглядає рефлексію як основне утворення, що виникає внаслідок опанування учнями навчальним матеріалом. Досягнення позитивного ефекту пов'язане з тим, що вирізнене вихідне поняття формується шляхом присвоєння сукупності історично вироблених способів дій, тому для учнів зрозумілішим є якраз те поняття, яке вводилося шляхом виконання таких дій. Звичайно, це відбувається завдяки тому, що простежується спосіб дії, який є його підгрунтям [4].

Виділений навчальний зміст певного фахового розділу було включено О. Савицькою у значну кількість навчальних ситуацій, погрупованих у три блоки (етапи), а вирішення пропонованих пізнавальних задач-проблем передбачало виконання ряду предметних та рефлексивних дій, спрямованих на засвоєння вичлененого вихідного відношення та стимулювання розвитку рефлексії. Запроваджена авторкою програма експериментального навчання дозволила досягти значних якісних зрушень у розвитку інтелектуальної рефлексії учнів, посприяла успішному формуванню системи теоретичних понять геометричної оптики і підтвердила дієвість та емпірично-розвивальний потенціал експериментальногенетичного методу [9].

У дослідженнях Я. Гошовського експериментально-генетичний метод обраний осердям розвивального інструментарію, зокрема, в контексті задіяння медіально-рефлексійних тренінгових підходів до педагогічного спілкування з депривованими підлітками. Провівши порівняльний аналіз виконання учнями педагогічних завдань у масовій загальноосвітній школі, школі-інтернаті, гімназії, ліцеї, школі пенітенціарного закладу, учений встановив відмінності у рецепції психолого-педагогічної інформації та констатував потужний розвивальний потенціал генетично-психологічного інструментарію, зокрема, експерименально-генетичного методу [4].

Апробація та запровадження вченими експериментально-генетичного методу в мережі навчально-виховних установ закритого типу (різнотипні школи-інтернати, пенітенціарні заклади, спеціалізовані школи тощо) дають нам підстави для розробки концептуальних генетично-психологічних засад із застосуванням цього плідного розвивального методу, розробленого С. Максименком. 
Приклад реального запровадження принципів генетичної психології в канву педагогічної взаємодії подав I. Секрет, активно використавши експериментально-генетичний метод для вивчення іншомовного писемного мовлення старшокласниками та студентами. Цим не раз підтверджено загальні широкі евристичні можливості методичних підходів, базованих на критеріях генетичної психології, так і дослідницький потенціал конкретних методичних прийомів, застосовуваних у сучасній вітчизняній психологічній науці. Корекційно-розвивальна програма 3 розвитку іншомовного писемного мовлення, розроблена на критеріях експериментально-генетичного методу, була впроваджена як експериментальна у навчальних закладах різного рівня (школа, технікум, університет). Запропоноване I. Секрет творче використання основних постулатів генетичної психології на рівні реальної психолого-педагогічної емпірії у плані методично-розвивальних прийомів посприяло не тільки виведенню навичок освоєння іншомовного писемного мовлення на якісно вищий рівень, а й появі в учнів таких психологічних новоутворень, як високий рівень мотивації засвоєння як іншомовного писемного мовлення, так й іноземної мови загалом; навички керування власними уявленнями та роздумами; підвищення рівня механізмів контролю та самоконтролю; формування нового типу когнітивного розвитку учнів, для якого характерне успішне оволодіння системою пізнавальних дій, адекватних структурі предметного змісту; сприяння подальшому розвитку самовизначення та встановлення свого місця у референтній групі; активний розвиток міжособистісних стосунків у навчальній групі тощо [10].

У контексті вивчення генези професіоналізму психологів добрий приклад подає Ж. Вірна, яка інтенсивно залучає доробки генетично-психологічної парадигми, зокрема постулюючи потребу експериментально-генетичного вивчення мотивації особистості, котра набуває фаху у різнотипних вищих навчальних закладах [1].

Отже, робота 3 психокорекції адикції підлітків може здійснюватися у концептуальному річищі генетичної психології, що дасть простір як для глибокого й різнобічного аналізу окремих теоретичних парадигм чи емпіричних досліджень, так і для систематизації багатогранного досвіду. Теоретичні постулати генетичної психології сприяють виявленню i формулюванню нових нетипових підходів до організації та проведення психологопедагогічних досліджень, наповнення їх конкретною реалістичністю та практичною ефективністю, розробленню засобів їхнього оптимального втілення у практику психологічних реалій. Згідно з концептуальними положеннями генетичної психології, особистість, моделюючи й реалізуючи власний генезис, є складною системою, що саморозвивається. Обов'язок психолога-практика - створити такі способи і форми вивчення, які б не переривали й не зупиняли його штучно, а співіснували б з ним. Таке симбіотичне співіснування повинно відбуватися за принципом сполучальності, тобто потрібно дати особистості вільно функціонувати і розвиватися за власними законами, але, водночас, надавати ій керовано такі природні й соціальні можливості, які підлягають емпіричній фіксації та верифікуванню.

Запровадження в реалії прикладного психологічного повсякдення генетичнопсихологічних засобів дає можливість встановити широкий фон особистісно-психологічних чинників і механізмів формування успішної психокорекційної роботи з адикцією підлітків та здійснити широкий і різновекторний збір емпіричних показників про динаміку психологічних характеристик і потенціалів особистісних ресурсів. Підкреслимо, що творче використання експериментально-генетичного методу в дослідженнях проблем психокорекції адиктивної поведінки підлітків є цілком природним і успішним, оскільки відповідає базовим принципам генетичної психології, адже передбачає формування у школярів іншого мислення, інших психологічних новоутворень за допомогою спеціального вимірювання та конструювання змісту психологічної практики.

1. Вірна Ж. П. Мотиваційно-смислова регуляція у професіоналізації психолога : дис. ... д-ра психол. наук : спец. 19.00.01. Луцьк, 2004, 437 с.

2. Выготский Л. С. История развития высших психических функцій. Собрание починений : в 6 m. 
Москва. : Педагогика, 1983. Т. 3. 368 с.

3. Глозман М. Культурно-исторический подход как основа нейропсихологии XXI века. Вопросы психологии. 2002. № 4. С. 62-68.

4. Гошовський Я. Генетична психологія як методологічна парадигма вивчення депривованої особистості. Психологічні перспективи. 2007. Вип. 10. С. 11-17.

5. Ковальчук 3. Я. Генетично-психологічні засади оптимізації педагогічної взаємодії : монографія / за ред. С. Д. Максименка. Львів : ЛьвДУВС, 2013. 610 с.

6. Ковальчук 3. Я. Експериментально-генетичний метод як потужний засіб дослідження оптимізації міжособистісного спілкування в освітньому просторі. Гуманітарний вісник ДВНЗ "Переяслав-Хмельницький державний університет імені Григорія Сковороди”. Дод. 1 до вип. 29, Т. II : “Тематичний випуск “Міжнародні Челпанівські психолого-педагогічні читання”. Київ : Гнозис, 2013. С. 56-63.

7. Крайг Г. Психология развития, Санкт-Петербург : Питер, 2002. 720 с.

8. Максименко С. Д. Генетическая психология (методологическая рефлексия проблем развития в психологии), Москва. : Рефл-бук; Київ, Ваклер, 2000. 320 с.

9. Максименко С. Д. Розвиток психіки в онтогенезі : у 2 т. Київ : Форум, 2002. Т. 1. 319 с. ; Т. 2.335 с.

10. Секрет I. В.Експериментально-генетичний метод дослідження іншомовного писемного мовлення у старшокласників та студентів. Теоретико-методологічні проблеми генетичної психології : матер. міжнар. наук. конфер., присвяченої 35-річчю наукової та педагогічної діяльності акад. С. Д. Максименка (17-18 грудня 2001 р., м. Київ). Київ : Міленіум, 2002. Т. 1. С. 256-260. 